\title{
THE FEBRUARY MEETING IN NEW YORK
}

The three hundred fifty-seventh meeting of the American Mathematical Society was held at Columbia University on Saturday, February 25, 1939. The attendance included the following one hundred ninety-six members of the Society:

C. R. Adams, R. B. Adams, R. P. Agnew, Leon Alaoglu, C. B. Allendoerfer, R. G. Archibald, Herbert E. Arnold, R. P. Bailey, S. F. Barber, Sr. M. A. Beamish, M. F. Becker, T. J. Benac, A. C. Berry, E. E. Betz, G. D. Birkhoff, W. Z. Birnbaum, Archie Blake, Gertrude Blanch, J. H. Blau, H. F. Bohnenblust, Samuel Borofsky, Joseph Bowden, C. B. Boyer, H. W. Brinkmann, A. B. Brown, J. H. Bushey, S. S. Cairns, A. D. Campbell, W. B. Campbell, M. E. Carlen, Alonzo Church, A. B. Coble, T. F. Cope, Richard Courant, Ruth Crucet, H. B. Curry, M. D. Darkow, Norman Davidowitz, M. M. Day, J. J. DeCicco, Jesse Douglas, Arnold Dresden, Nelson Dunford, W. D. Duthie, J. E. Eaton, H. T. Engstrom, Paul Erdös, J. M. Feld, Aaron Fialkow, T. S. Fiske, D. A. Flanders, M. C. Foster, R. M. Foster, Philip Franklin, K. O. Friedrichs, T. C. Fry, G. N. Garrison, J. J. Gergen, B. P. Gill, R. L. Gilman, M. C. Graustein, W. C. Graustein, M. C. Gray, M. B. Greenebaum, Laura Guggenbühl, M. B. Haberzetle, D. W. Hall, N. A. Hall, Israel Halperin, D. C. Harkin, Philip Hartman, G. A. Hedlund, Fritz Herzog, E. H. C. Hildebrandt, Banesh Hoffmann, Lulu Hofmann, M. A. Holly, G. M. Hopper, Harold Hotelling, S. E. Hotelling, E. M. Hull, R. P. Isaacs, R. A. Johnson, A. W. Jones, B. W. Jones, Mark Kac, E. R. van Kampen, Edward Kasner, L. S. Kennison, B. F. Kimball, J. R. Kline, L. A. Knowler, E. R. Kolchin, Solomon Lefschetz, B. A. Lengyel, Howard Levi, Marie Litzinger, E. R. Lorch, A. N. Lowan, R. S. McKee, Brockway McMillan, L. A. MacColl, H. F. MacNeish, Dorothy Manning, W. T. Martin, A. E. Meder, H. L. Mintzer, J. A. Mira, Virginia Modesitt, Deane Montgomery, Lillian Moore, A. P. Morse, Marston Morse, H. T. Muhly, D. C. Murdoch, F. J. Murray, Tadasi Nakayama, D. S. Nathan, John von Neumann, Oystein Ore, J. C. Oxtoby, C. K. Payne, B. J. Pettis, Everett Pitcher, E. L. Post, Walter Prenowitz, R. G. Putnam, H. A. Rademacher, H. W. Reddick, M. S. Rees, R. W. Rempfer, H. J. Riblet, Moses Richardson, R. G. D. Richardson, H. E. Robbins, J. H. Roberts, M. S. Robertson, S. L. Robinson, Benjamin Rosenbaum, R. A. Rosenbaum, Barkley Rosser, S. G. Roth, O. K. Sagen, Arthur Sard, Samuel Saslaw, O. F. G. Schilling, Abraham Schwartz, Hyman Serbin, I. M. Sheffer, Jacob Sherman, Max Shiffman, L. G. Simons, James Singer, Abraham Sinkov, P. A. Smith, Virgil Snyder, V. E. Spencer, M. H. Stone, W. C. Strodt, D. J. Struik, R. R. Struik, M. M. Sullivan, C. S. Sutton, J. L. Synge, J. M. Thomas, C. B. Tompkins, C. C. Torrance, E. M. Torrance, A. W. Tucker, J. W. Tukey, Annita Tuller, S. M. Ulam, Oswald Veblen, R. J. Walker, Henry Wallman, J. V. Wehausen, Louis Weisner, M. E. Wells, Hermann Weyl, A. P. Wheeler, O. L. Wheeler, H. S. White, A. L. Whiteman, Hassler Whitney, G. T. Whyburn, D. V. Widder, Norbert Wiener, C. R. Wilson, H. P. Wirth, Jacob Wolfowitz, H. A. Wood, H. N. Wright, W. M. Wynne, Marie York, Leo Zippin, H. S. Zuckerman.

The meeting opened Saturday morning in three sessions: Algebra and Number Theory, Professor M. H. Stone presiding; Analysis, 
Vice President C. R. Adams presiding; and Geometry and Topology, Professors J. R. Kline and A. D. Campbell presiding. At the afternoon general session, at which Vice President J. F. Ritt presided, Professor R. P. Agnew gave an address entitled Properties of generalized definitions of limit.

A meeting of the Council was held on Saturday at 12:30 P.M. in the Faculty Club of Columbia University, Vice President Ritt in the chair. The election of the following four persons to membership in the Society was announced by the Secretary:

Professor Joseph T. O'Callahan, Holy Cross College;

Dr. Henry William Steinhaus, Equitable Life Assurance Society of the U.S., New York, N.Y.;

Mr. Robert R. Stoll, Rensselaer Polytechnic Institute;

Mr. Benjamin Joseph Tepletsky, Ohio State University.

It was reported that the following had been elected as nominees on the Institutional Memberships of the various institutions and departments:

University of California: Messrs. Charles Amos Heyes, Arthur Elmore Marston, and William Francis Whitmore.

Columbia University: Miss Ruth Crucet, Messrs. Rufus Philip Isaacs, Donald Percy Ling, and Harry Sohn, and Mrs. Marie York.

Duke University: Messrs. Paul Wilner Gilbert, Donald M. Seward, and Luther Irwin Wade.

Division of Mathematics, Harvard University: Messrs. Francis Parkman Byerly, Richard Frederick Clippinger, Thomas Jefferson Coolidge, Clinton Hoadley Crane, Nathan Hayward, Lynn Harold Loomis, Douglas Tillman McClay, George Putnam, and Abraham Spitzbart.

Haverford College: Mr. Philip Martin Whitman.

Iowa State College: Mr. Donald Hill Rock.

The Johns Hopkins University: Dr. Mark Kac.

Lehigh University: Messrs. Francis Ernest Carner and William Reagle Transue.

Stanford University: Miss Rhoda Manning and Mr. Robert Wayman Rector.

Wesleyan University: Mr. Arthur Southcomb Day.

Western and Southern Life Insurance Company: Professor Victor Cyril Stechschulte. University of Wisconsin: Messrs. James Henry Bell, Edwin Louis Crow, Vladimir Morkovin, Homer Edward Newell, Jr., Robert Dickerson Specht, Bonnie Madison Stewart, and James Audley Ward.

Department of Mathematics, Yale University: Mr. Theodore Joseph Benac.

The following appointments by President Evans and Vice President Ritt were reported: as representative of the Society at the Centennial Celebration of Duke University to be held at Durham, North Carolina, on April 21, 22, and 23, Professor E. T. Browne; as a committee to make recommendations to the Council regarding the use of a bequest from the estate of E. W. Brown, Professors W. R. Long- 
ley (chairman), Virgil Snyder, and K. P. Williams; as a Committee on Nomination of Officers and Members of the Council for 1940, Professors Dunham Jackson (chairman), G. A. Bliss, D. J. Struik, T. Y. Thomas, and Marie Weiss; as a committee to consider the location of the Annual Meeting of 1940, Professors W. L. Ayres (chairman), E. T. Browne, and Philip Franklin; as a committee to consider freer methods of nominating and electing members-at-large in the Council, Dean L. P. Eisenhart (chairman), Professors C. R. Adams, W. C. Graustein, W. T. Martin, and A. D. Michal; as a committee on the place of meetings, Professors E. W. Chittenden (chairman), W. B. Carver, W. L. Hart, E. J. McShane, and H. B. Phillips; as a committee on the use of the accrued income from special funds, Professors T. H. Hildebrandt (chairman), Arnold Dresden, W. B. Fite, J. L. Walsh, and Anna Pell Wheeler.

It was announced that Professor Theodore von Kármán has accepted the Society's invitation to give the fifteenth Josiah Willard Gibbs Lecture at Columbus.

In place of the usual February and April meetings, only one spring meeting will be held in 1940. An invitation was received from George Washington University for this meeting.

The Committee on the Abstract Journal reported progress.

Titles and cross references to the abstracts of the papers read at this meeting follow below. Papers whose abstract numbers are followed by the letter $t$ were read by title. The papers numbered 1 to 8 were read before the section for Algebra and Number Theory; those numbered 9 to 15 before the section for Analysis; those numbered 16 to 22 before the section for Geometry and Topology; papers numbered 23 to 51 were read by title. Paper 5 was read by Dr. Murdoch, paper 10 by Mr. Wolfowitz, paper 13 by Mr. McMillan, paper 18 by Dr. Schilling, and paper 20 by Professor Kasner. Dr. Abraham Wald was introduced by Professor Harold Hotelling, Dr. Mark Kac by Professor Aurel Wintner, Mr. R. P. Isaacs and Miss Annette Vassell by Professor Edward Kasner, Miss Harlan C. Miller and Mr. R. L. Swain by Professor R. L. Moore, and Professor Harald Cramér by Professor Einar Hille.

1. J. H. Blau: A characterization of algebraic fields of prime characteristic. (Abstract 45-3-109.)

2. H. J. Riblet: Symmetric differential expressions. (Abstract 45-3125.)

3. Barkley Rosser: On the first case of Fermat's last theorem. (Abstract 45-1-96.) 
4. Abraham Sinkov: $A$ note on a paper by J. A. Todd. (Abstract 45-3-126.)

5. D. C. Murdoch and Oystein Ore: Ideal theory in non-associative rings. (Abstract 45-3-122.)

6. Tadasi Nakayama: On Frobeniusean algebras. I. (Abstract 45-3123.)

7. Oystein Ore: Chain properties in finite groups. (Abstract 45-3124.)

8. J. E. Eaton: Associative multiplicative systems. (Abstract 45-3111.)

9. Abraham Wald: Lower and upper limits of a distribution function determined by moments and inequalities satisfied by moments. (Abstract 45-3-150.)

10. Abraham Wald and Jacob Wolfowitz: Confidence limits for continuous distribution functions. (Abstract 45-3-128.)

11. Philip Hartman: An asymptotic formula for exponential integrals. (Abstract 45-3-114.)

12. Mark Kac: Statistics and power series with gaps. (Abstract 453-117.)

13. Norbert Wiener and Brockway McMillan: $A$ new method in statistical mechanics. (Abstract 45-3-133.)

14. Vivian E. Spencer: Extensions of theorems of Markoff and Krein. (Abstract 45-1-97.)

15. E. R. Kolchin: On the basis theorem for systems of differential polynomials. (Abstract 45-3-119.)

16. R. P. Isaacs: A geometric interpretation of the difference quotient of polygenic functions. (Abstract 45-1-90.)

17. S. S. Cairns: Planes transversal to polyhedral manifolds. (Abstract 45-3-110.)

18. Saunders MacLane and O. F. G. Schilling: Zero-dimensional branches of rank one on algebraic varieties. (Abstract 45-3-120.)

19. S. M. Ulam: On $\epsilon$-isomorphic transformations. Preliminary report. (Abstract 45-3-127.)

20. Edward Kasner and J. J. DeCicco: Curvature element transformations which preserve integrable fields. (Abstract 45-3-118.)

21. J. J. DeCicco: The polygenic functions whose associated series are equiparallel series. (Abstract 45-1-84.)

22. J. M. Feld: Conformal and inversive invariants of plane curves and horn angles. (Abstract 45-3-112.)

23. Garrett Birkhoff: The mean ergodic theorem. (Abstract 45-177-t.) 
24. Garrett Birkhoff and Morgan Ward: A characterization of Boolean algebras. (Abstract 45-1-78-t.)

25. O. K. Bower: Paradoxes involving mathematical expectation. (Abstract 45-1-80-t.)

26. O. K. Bower: The equation $f(x+y)=f(x) f(y)$ and a system of functional equations depending upon its solution. (Abstract 45-1-81-t.)

27. George Comenetz: The limit of the ratio of arc to chord for a space curve. (Abstract 45-1-82-t.)

28. J. J. DeCicco: The analogue of the Moebius group of circular transformations in the associated Kasner plane. (Abstract 45-1-83-t.)

29. F. C. Gentry: Cremona involutions determined by a pencil of surfaces. (Abstract 45-3-113-t.)

30. Einar Hille: Remarks concerning group spaces and vector spaces. (Abstract 45-1-89-t.)

31. Charles Hopkins: An extension of a theorem of Remak. (Abstract 45-3-115-t.)

32. Nathan Jacobson: An application of $E$. H. Moore's determinant of a hermitian matrix. (Abstract 45-3-116-t.)

33. B. O. Koopman: The axioms and algebra of intuitive probability. (Abstract 45-1-92-t.)

34. E. H. Larguier: On the foundations of mathematics. (Abstract 45-1-93-t.)

35. Harlan C. Miller: Some methods of characterizing certain atriodic continua. (Abstract 45-3-121-t.)

36. Barkley Rosser: Definition by induction in Quine's "New foundations for mathematical logic." (Abstract 45-1-95-t.)

37. R. H. Sorgenfrey: A theorem on atriodic continua. (Abstract 45-1-63-t.)

38. R. L. Swain: On continua obtained from sequences of simple chains of connected regions. (Abstract 45-1-98-t.)

39. Annette Vassell: Sectional families of curves. (Abstract 45-199-t.)

40. A. D. Wallace: Non-boundary sets. (Abstract 45-3-129-t.)

41. A. D. Wallace: Some characterizations of interior transformations. (Abstract 45-3-130-t.)

42. J. L. Walsh: On the circles of curvature of the images of circles under a conformal map. (Abstract 45-3-131-t.)

43. Morgan Ward: $A$ note on divisibility sequences. (Abstract 45-1101-t.)

44. Morgan Ward: Ring homomorphisms which are also lattice homomorphisms. (Abstract 45-1-104-t.) 
45. Morgan Ward and R. P. Dilworth: Lattice theory of ova. (Abstract 45-1-107-t.)

46. Hassler Whitney: On products in a complex. II. (Abstract 45-3132-t.)

47. Harald Cramér: On the representation of a function by certain Fourier integrals. (Abstract 45-5-170-t.)

48. H. T. Engstrom: A note on fundamental systems of symmetric functions. (Abstract 45-3-137-t.)

49. D. H. Lehmer: On the remainders and convergence of the series for the partition function. (Abstract 45-3-140-t.)

50. Max Zorn: Continuous groups and Schwarz' lemma. (Abstract 45-3-151-t.)

51. Mark Kac and E. R. van Kampen: Circular equidistribution and statistical independence. (Abstract 45-5-194-t.)

T. R. Hollcroft, Associate Secretary 